\title{
Banks' procyclical behavior: Does provisioning matter?*
}

\author{
Vincent Bouvatier ${ }^{\dagger} \quad$ Laetitia Lepetit ${ }^{\ddagger}$
}

October 2006

\begin{abstract}
A panel of 186 European banks is used for the period 1992-2004 to determine if banking behaviors, induced by the capital adequacy constraint and the provisioning system, amplify credit fluctuations. Our finding is consistent with the bank capital channel hypothesis, which means that poorly capitalized banks are constrained to expand credit. We also find that loan loss provisions (LLP) made in order to cover identified credit losses (non discretionary LLP) amplify credit fluctuations. Indeed, non discretionary LLP evolve cyclically. This leads to misevaluation of expected credit risk which affect banks' incentives to grant new loans since lending costs are misstated. By contrast, LLP used for management objectives (discretionary LLP) do not affect credit fluctuations. The findings of our research are consistent with the call for the implementation of a dynamic provisioning system in Europe.
\end{abstract}

JEL classification: G21

Keywords: bank lending, loan loss provisions, capital requirement

\footnotetext{
${ }^{*}$ We would like to thank Carlos Bautista, Christian Bordes, Thérèse Chevallier-Farat, Jézabel Couppey-Soubeyran, Andy Mullineux, Emmanuelle Nys, Philippe Rous, Alain Sauviat and Amine Tarazi for their assistance and their helpful comments. The usual disclaimer applies.

†Université de Rennes 1, CREM - CNRS (UMR 6211), Faculté des Sciences Economiques, 7 place Hoche, 35065 Rennes Cedex, France. e-mail: vincent.bouvatier@univ-rennes1.fr

${ }^{\ddagger}$ Corresponding author: Université de Limoges, LAPE, 5 rue Félix Eboué, 87031 Limoges Cedex, France. Tel: +33-555-1492-13, laetitia.lepetit@unilim.fr
} 


\section{Introduction}

Much concern has been recently expressed about factors explaining fluctuations in bank lending. Central banks, as well as banking regulators, are concerned since such factors could exacerbate the business cycle, cause financial instability and misallocate lending resources. The literature on fluctuations in bank lending is based on the work of Bernanke and Blinder (1988) who introduced the credit market equilibrium in a textbook IS-LM model and analyzed the interaction between monetary policy and bank lending. A better understanding of the economy's response to a monetary policy shock requires therefore to consider a bank lending channel (Bernanke and Gertler, 1995) which emphasizes the role of imperfections in the market for bank debt. This hypothesis is empirically supported by Kashyap and Stein (1995, 2000) for American banks and by Ehrmann et al. (2003) for European banks. Imperfections in the market for bank capital can also be stressed to explain fluctuations in bank lending. Van den Heuvel (2002) focuses on capital requirements and defines a bank capital channel by which monetary policy can change the supply of bank loans through its impact on bank equity. These two channels do not only operate through changes in monetary policy. They are also relevant in explaining the impact of macroeconomic conditions and changes in banking regulation on bank lending.

In this paper, we point out another factor which may amplify the cyclicality of bank lending: the provisioning system. Provisioning rules and capital requirements are linked through the coverage of credit risk: the conceptual framework of credit risk management supposes that expected losses have to be covered by loan loss provisions while unexpected losses have to be covered by bank capital. While regulatory constraint explicitly links the expansion of bank lending with bank capital, such a constraint does not exist on provisioning rules. However, loan loss provisions have a direct impact on banks profit. An underestimated expected credit risk could reinforce banks' incentives to grant new loans since lending costs are understated. In addition, increases in loan loss provisions due to deterioration in loan portfolio quality can lead to a decrease in banks capital if losses are too strong. Credit risk management without provisioning rules covering expected credit risk may therefore have procyclical effects. This concern is all the more important as banking regulators and academic researchers focus mainly on capital requirements and tend to disregard provisioning practices. Hence, in this paper we analyze if the evolution of loan loss provisions may explain changes in 
banks' lending behavior over the business cycle.

The relationship between loan loss provisions and credit supply fluctuations has to be cautiously analyzed because loan loss provisions merge different information and behaviors. The literature distinguishes two components $^{1}$. The first one, called the non discretionary component, is made in order to cover expected credit losses in a bank's loan portfolio (Whalen, 1994; Beaver and Engel, 1996). This kind of provisioning system is said to be backward-looking since banks mainly relate non discretionary provisions to identified credit losses. During economic upswings, few credit losses are identified and the level of loan loss provisions is low. During downturns, however, loan loss provisions increase because loan defaults are usually high during this period. As a result, the non discretionary component is a driving force in the cyclicality of loan loss provisions and leads to a misevaluation of expected credit losses. The expected credit risk appears as soon as the loan is granted and not only during the downturn when the losses are finally identified. In particular, Keeton (1999) and Jiménez and Saurina (2005) show that an increase in loan growth during an expansionary phase leads to higher loan losses during the slowdown. Expected credit losses are therefore under-provisioned during an upswing phase. Conversely, banks have to charge provisions too late during the downturn. The cyclicality of loan loss provisions directly affect bank profits and bank capital which could influence the bank's incentive to grant new loans and increase the cyclicality of its lending.

The second component, called the discretionary component, is due to the utilization of loan loss provisions for management objectives. At least three different discretionary actions can be distinguished (Liu et al., 1997; Ahmed et al., 1999; Lobo and Yang, 2001). The first one is the income smoothing behavior. Banks have incentives to smooth earnings over time. When earnings are expected to be low, loan loss provisions are deliberately understated to mitigate adverse effects of other factors on earnings. On the other hand, when earnings are unusually high, banks choose discretionary income-reducing accruals. Thus, under the incomesmoothing behavior, banks choose accruals to minimize the variance of reported earnings. This implies that loan loss provisions increase during an expansionary phase and decrease during a recession phase. The two other discretionary actions are concerned with capital management and signaling. With regard to capital

\footnotetext{
${ }^{1}$ Accounting practices distinguish specific provisions and general provisions (Cortavaria et al., 2000). Specific provisions are defined by specific accounting rules. They depend on identified credit losses and they will increase specific loan loss reserves which are deducted from assets. General provisions have to cope with expected losses and will be added to general loan loss reserves on liabilities, but banks do not implement rigorous and statistical methods to compute them. Consequently, general provisions depend partially on expansion of total loans and they are manipulated by discretionary behaviors of bank managers.
} 
management, capital-constrained banks can use discretionary accruals to achieve regulatory-capital targets.

General and specific provisions reduce Tier 1 capital via their effect on earnings and then poorly capitalized banks could be less willing to make loan loss provisions However, general provisions are also included as components of Tier 2 capital and deduced from risk-weighted assets ${ }^{2}$. An increase in general provisions may actually increase the regulatory capital, especially if the increase in Tier 2 is larger than the decrease in Tier 1 capital. To the extent that such discretionary behavior increases regulatory capital without a corresponding reduction in risk of insolvency, it constitutes a regulatory capital arbitrage. The last discretionary behavior occurs when banks use loan loss provisions to signal their financial strength. The bank manager can signal that the earning power of the bank is strong enough to absorb future potential losses by increasing current loan loss provisions.

The objective of this paper is to analyze the effect of the provisioning system on fluctuations in bank lending in Europe. In particular, we attempt to determine if loan loss provisions amplify the credit cycle. Using a panel of European banks for the period 1992-2004, we estimate the non discretionary and discretionary components of loan loss provisions in order to individually isolate their impact on banks lending. The concern about the impact of loan loss provisions on credit cycle is particularly relevant for the debate between financial supervisors and accounting authorities about the reform in bank provisioning systems. The current provisioning system in Europe is backward-looking (excluding Spain and Portugal since recent years) and such a system may amplify the cyclicality of bank lending. In recent years, there have been calls (Trichet, 2000; Poveda, 2000; Crockett, 2000 and Borio et al., 2001) for more forward-looking provisioning decisions to mitigate the potential problem that may arise from the cyclicality of lending and bank profitability. But there is no consensus about the way in which this should be achieved: dynamic provisioning ${ }^{3}$

\footnotetext{
${ }^{2}$ General provisions can increase loan loss reserves of up to $1.25 \%$ of risk weighted assets, the excess will be deducted from Tier1.

${ }^{3}$ With a statistical or dynamic provisioning system, general and specific provisions are created continuously in the traditional manner. General provisions are established as usual to cover expected losses as a given proportion of the total loan portfolio, which are, however, not connected with direct assets and are for unspecified losses. Specific provisions are created to cover the expected impairment of assets based on problem loans. In addition to these provisions, the statistical provision is formed with purpose of anticipating risks arising from changes in business cycles for each risk category. The statistical provision records the expected losses connected with the initial portfolio in a way that total provisions (specific, general and statistical) created over the years are smoothed. The statistical provision increases in periods of economic growth, complementing net specific provisions, which are rather low in these periods compared to total loans. Such a system was established in Spain, Portugal and Australia. For a more detailed discussion on this issue, see Fernandez de Lis et al. (2001), Borio et al. (2001) and Mann and Michael (2002).
} 
promotes banking stability whereas Full Fair Value Accounting ${ }^{4}$ (FFVA) promotes market discipline.

The remainder of the paper is organized as follows. Section 2 reviews the literature on bank behavior and procyclicality. Section 3 reports the empirical methodology employed to differentiate the discretionary and non discretionary components of loan loss provisions. Section 4 presents estimates of the impact of provisioning practices on credit fluctuations. Section 5 discusses the credit cycle and dynamic provisioning practices. Concluding remarks are presented in the final section.

\section{Related literature on bank behavior and procyclicality}

The literature which analyzes fluctuations in bank lending behavior provides some empirical evidence of cyclicality. Asea and Blomberg (1998), using US data from 1977 to 1993, show that bank lending evolves cyclically, affecting aggregate economic activity. In addition, Peek et al. (2003) and Lown and Morgan (2006) clearly identify the effects of loan supply on fluctuations in credit and GDP which supports the existence of the bank lending channel ${ }^{5}$.

Bikker (2004), for a panel of 26 OECD countries over the period 1979-1999, finds that lending at a macroeconomic level is strongly dependent on demand factors, measured by cyclical variables such as real GDP growth, inflation, unemployment and real money supply. However, such macroeconomic approach understates the role played by bank characteristics. This is because of the identification problem; it is difficult to separate the role of loan demand from that of loan supply. This difficulty has prompted researchers to focus on microeconomic panel data to explore some of the cross-sectional implications of the bank lending view. Much concern focused on the impact of monetary policy. The responses of banks to changes in monetary policy may differ, depending on their characteristics. The idea behind this is that some types of banks are more capable than others to offset a monetary policy shock. Indeed, changes in the money market rate affect

\footnotetext{
${ }^{4}$ Full fair value accounting tries to approximate as closely as possible the value that the asset would have if it were traded on the market. This implies that the value of a bank's problem assets will fall immediately, in contrast with historical accounting where banks have to make reserves for the difference between the book value and the actual value. One of the benefits of fair value accounting is that it offers better information to investors and supervisors. However, the frequent changes in the value of assets exposed to market price fluctuations tend to amplify capital volatility and thus lending cycles. See Jackson and Lodge (2000) and the Joint Working Group Standard Setters (2000) for an overview of the debate on fair value accounting.

${ }^{5}$ We underline interactions between the credit cycle and the business cycle for different European countries over the period 1980-2004 using Granger causality tests and comtemporaneous correlations. The results are not presented in the paper but are available from the authors upon request.
} 
the cost of funding but this has a limited effect on lending when banks can easily raise non-deposit funding or when banks own a buffer of liquid assets. Kashyap and Stein (1995) originally proposed a reduced form dynamic equation for bank loans using a panel of American banks over the period 1976-1992. Their findings are consistent with the bank lending channel view and show that loan growth of large banks and small banks respond differently to a monetary policy shock. Other studies on American banks, following the approach of Kashyap and Stein (1995), find that the impact of the bank lending channel is also greater for banks with fewer liquid assets and less capital (Kashyap and Stein, 2000; Kishan and Opiela, 2000). The bank lending view is relevant for European banks as well (Altunbas et al., 2002; Ehrmann et al 2003) even if studies on the role of banks capital display mixed results. Individual country estimates can give more conclusive results (see Gambacorta and Mistrulli (2004) and Gambacorta (2005) for the Italian case).

The studies mentioned above point out a bank lending channel based on imperfections in the market for bank debt. Imperfections in the market for bank equity are also stressed to explain the impact of bank capital on lending and then to define a bank capital channel (Van den Heuvel, 2002). The bank capital channel assumes a maturity mismatch between assets and liabilities. An increase in the money market rate is therefore supposed to affect more strongly interest rates on bank's liabilities than interest rates on bank's assets. Consequently, the increase in the money market rate implies a reduction in a bank profit and therefore in the bank's capital. Since issuing equity is costly and banks have to meet capital requirements, a monetary policy shock can affect bank lending. Van den Heuvel (2002) shows that the bank capital channel concerns all low-capitalized banks and not only banks with capital binding constraint. Theoretical investigations (Chami and Cosimano, 2001; Furfine, 2001 and Zicchino, 2005) also emphasized the role of macroeconomic conditions and changes in banking regulation to explain the impact of capital requirements on bank lending.

The bank capital channel is consistent with empirical findings related to the 1990-1992 "credit crunch" in the United States. These studies focus directly on the impact of capital requirements on bank lending and try to assess whether there was a "capital crunch" caused by increased capital requirements or if more stringent regulatory practices occurred at the beginning of the 1990 's ${ }^{6}$. Bernanke and Lown (1991) find a positive correlation between loan growth and changes in bank capital during 1990-1991 while Hancock and

\footnotetext{
${ }^{6}$ The BIS risk-based capital standards began to phase in at the end of 1990 and were fully implemented in 1992.
} 
Wilcox (1998) and Peek and Rosengren (1995) detect a positive effect of bank capital requirements on credit growth during the same period. Brinkmann and Horwitz (1995) also find a positive effect on loan growth, but only for large banks. Wagster (1999) shows that stricter supervision, which occurred during the period 1990-92 in Canada, UK and the USA, implies that less credits were extended to lower-risk investments such as government bonds.

Misevaluation of credit risk over the business cycle represents another feature which may explain fluctuations in bank lending. In phases of economic boom, banks are inclined to take on greater risks, owing to their basically positive anticipations as regards the course of the economy and future trends. By contrast, banks are excessively pessimistic during cyclical downturns if they overstate credit risk. Disaster myopia (Guttentag and Herring, 1984, 1986), herd behavior (Rajan, 1994) and the institutional memory hypothesis (Berger and Udell, 2003) account for misevaluation of credit risk. Disaster myopia emphasizes that banks tend over time to underestimate the probability of low-frequency shocks while herd behavior focuses on the idea that banks management is obsessed with short-term concerns and perception of reputation. As for the institutional memory hypothesis, it stresses that current loan officers ease credit standards over time as the previous loan bust is not remembered because of loan officer turnover.

Backward-looking provisioning systems also contribute to the misevaluation of credit risk. Whalen (1994) and Beaver and Engle (1996) identify a non discretionary component in loan loss provisions related to contemporaneous problem loans. Besides, Laeven and Majnoni (2003) and Bikker and Metzemakers (2005) show that provisioning behavior is related to the business cycle. These studies therefore highlight that the ratio of loan loss provisions to total assets exhibit a strong cyclicality. This is notably documented for France (Clerc et al., 2001), Austria (Arpa et al., 2001), Spain (Fernandez de Lis et al., 2001) and United Kingdom (Pain, 2003). Expected credit losses are therefore understated during upswings and overstated during downturns. A time-lag can notably be stressed between riskier loans which are granted during the peak of the business cycle (Keeton, 1999; Jiménez and Saurina, 2005) and loan loss provisions which are built up only during the next downturn according to backward-looking rules. This pattern is a major factor in driving the cyclical nature of recorded bank profits and bank capital. In particular, Jordan et al. (2002) emphasize that the cyclicality of loan loss provisions is reflected in bank capital. As a result, provisioning 
rules in a backward-looking system can be seen as contributing to the overall cyclicality of the financial system and the macro-economy more generally (Borio et al., 2001).

Although the recent debate about whether current practices of provisioning are biased towards procyclical bank behavior, there is no study to our knowledge which explicitly examines the impact of loan loss provisions on bank lending. Shrieves and Dahl (2002) - analyzing the utilization of the discretionary accounting practice of the Japanese banks during 1989-1996 - find a negative and significant relationship between loan loss provisions and year-on-year change in total loans. This result is consistent with the hypothesis that loan loss provisions influence credit cycles. However, to test explicitly the impact of loan loss provisions on the fluctuations of bank lending, the discretionary component and the non discretionary component need to be distinguished. Indeed, the cyclical behavior of non discretionary provisions should reinforce the cyclical nature of bank lending. On the contrary, the discretionary component, through the income smoothing behavior, may reduce the procyclicality of bank lending.

\section{Estimation of the discretionary and non discretionary compo- nents of loan loss provisions}

To test the impact of loan loss provisions (LLP) on fluctuations in bank lending, we need to estimate the discretionary and the non discretionary components of LLP. We use a methodology similar to the one developed by Ahmed et al. (1999).

\subsection{Data and descriptive statistics}

We use a sample consisting of an unbalanced panel of annual report data from 1992 to 2004 for a set of European commercial and cooperative banks ${ }^{7}$ established in 15 European countries: Austria, Belgium, Denmark, Finland, France, Germany, Italy, Luxembourg, Netherlands, Norway, Portugal, Spain, Sweden, Switzerland, United Kingdom (see Appendix, Table A1). The bank data used for the estimates come from

\footnotetext{
${ }^{7}$ We choose a sample of commercial and cooperatives banks to workon an harmonized set of banks. We do not exclude from our sample banks involved in mergers or acquisitions. Nervetheless, few banks present a structural break in the balance sheet: less than 20 banks present a variation of total asset over the period greater than $20 \%$ (the sample mean of the variation of total asset is $10.58 \%$ ).
} 
Bankscope Fitch $\mathrm{IBCA}^{8}$. A majority of banks do not give information on some variables needed by this study (especially non performing loans and total capital ratio). Also we delete banks with less than five years of time series observations. Moreover, we exclude outliers by eliminating the extreme bank/year observations when a variable present extreme values ${ }^{9}$. The final sample consists of 186 European banks out of the 2 513 available at the beginning (see Table A1 in the appendix for details). However, our unbalanced sample represents a significant part of total loans available in Bankscope Fitch IBCA. The average cover rates of total loans are around $37 \%$ in 1992 and 54\% in 2004 (see Appendix, Table A1).

Descriptive statistics show that deposits are the main resource (65.67\%) and loans are the main banks' assets (58.53\%) (see Appendix, Table A2). These assets seem carefully managed as mean ratios of LLP to total assets and nonperforming loans to gross loans are respectively $0.41 \%$ and $5.08 \%$. Furthermore, the total capital ratio is $12.43 \%$. Thus, on average, banks are well capitalized with sufficient capital buffers.

\subsection{Modelling bank provisions}

Empirical evidence and economic theory (Beaver and Engel, 1996; Liu et al., 1997; Ahmed et al., 1999; Lobo and Yang, 2001) suggest a number of factors which may explain the choice of LLP. These may be grouped into three classes.

\subsubsection{Non discretionary behaviors}

The non discretionary component of LLP reflects expected losses but backward-looking rules based on identified credit losses give a strong cyclicality to this component. The model includes three variables which represent the risk of a bank's portfolio. The ratio of non performing loans to gross loans at the end of the year $t\left(N P L_{i t}\right)$ and the first difference of $N P L_{i t}\left(\Delta_{t+1 / t} N P L_{i t}=N P L_{i t+1}-N P L_{i t}\right)$ are good indicators of the risk of default on banks' loans. Hence, we expect a positive relationship between these two variables and LLP. We also include the risk of default for the overall credit portfolio, measured by the ratio of loans to total asset $\left(L_{i t}\right)$. The coefficient associated with this variable should also be positive.

\footnotetext{
${ }^{8}$ All the banks in our sample publish their annual financial statements at the end of the calendar year.

${ }^{9}$ The outliers represent 125 banks of the banks excluded of our sample ( $5 \%$ approximately of the initial sample). Thus most of the banks were deleted because we miss data about some variables.
} 


\subsubsection{Discretionary behaviors}

The discretionary component of LLP results from three different management objectives.

The income smoothing behavior

Under the income smoothing hypothesis, banks understate (overstate) LLP when earnings are expected to be low (high) relative to that of other years (inter-temporal smoothing). If banks use LLP to smooth earnings, then we would expect a positive relation between earnings before taxes and loan loss provisions $\left(E R_{i t}\right)$ and LLP. As the propensity to smooth income is higher for banks with good performance relative to banks with moderate current performance, we introduce a dummy variable which takes the value of $E R_{i t}$ for banks with positive earnings before taxes and loan loss provisions and 0 otherwise $\left(E R \_H_{i t}\right)$. We should find a positive coefficient for $E R \_H_{i t}$ if there is non linearity in the relation between LLP and earnings.

\section{The capital management behavior}

Poorly capitalized banks can use LLP to manage regulatory capital. We compute the variable $T C R L_{i t}$ which takes the value of the total capital ratio (TCR) minus 8 and divided by 8 when observations for bank $i$ are in the first quartile of TCR and 0 otherwise. A positive correlation between LLP and TCRL $L_{i t}$ could be expected if poorly capitalized banks are less willing to make LLP (Shrieves and Dahl, 2002). However, accounting relations could also influence the relation between bank capital and loan loss provisions. Regulatory capital is composed of Tier 1 - which includes equity and retained earnings - and Tier 2 - which includes subordinated debt and loan loss allowances. LLP are therefore positively correlated to Tier 2 and negatively to Tier 1 . If regulatory capital variations are more related to retained earnings than loan loss allowances, correlation should be negative between LLP and $T C R L_{i t}{ }^{10}$.

The signaling behavior

Banks can also use LLP to signal their financial strength. Beaver et al. (1989) suggest that loan loss provisions can indicate that "management perceives the earnings power of the bank to be sufficiently strong that it can withstand a hit to earnings in the form of additional loan loss provisions". If signaling is an important incentive in choosing LLP, then we should observe a positive relation between LLP and changes

\footnotetext{
${ }^{10}$ We use in our study the total capital ratio (TCR = TIER1+TIER2) because a majority of banks do not give specific information on their level of TIER 1 and TIER 2.
} 
in future earnings before taxes and LLP (Whalen, 1994; Ahmed et al., 1999). The variable $S I G N_{i t}$, defined as the one-year-ahead changes of earnings before taxes and loan loss provisions $\left(S I G N_{i t}=\left(E R_{i t+1}-\right.\right.$ $\left.E R_{i t}\right) / 0.5\left(T A_{t}+T A_{t+1}\right)$, where TA is the total asset), is computed to test the signaling hypothesis. A positive correlation with LLP is expected.

\subsubsection{Macroeconomic influences on asset quality}

The macroeconomic environment should affect the ability of borrowers to repay banks' assets. The private sector wealth will vary with the economic cycle, so we introduce the annual growth rate of GDP, $\dot{y}_{i t}$. Some studies have empirically studied the economic cycle as a determinant of loan loss provisions (see Pain (2003) for UK banks, Fernandez de Lis et al. (2001) for the Spanish case, Cavallo and Majnoni (2001), Laeven and Majnoni (2003) and Bikker and Metzemakers (2005)). They find a significant and negative impact on provisions: loan losses increase (and hence LLP) when $\dot{y}_{i t}$ decreases. Thus, we expected a negative sign for the variable $\dot{y}_{i t}$.

\subsubsection{Model specification}

Equation (1) models the relationship between loan loss provisions and the explanatory variables defined above:

$$
\begin{aligned}
L L P_{i t}= & \alpha_{0}+\underset{(+)}{\alpha_{1} L L P_{i t-1}}+\underset{(+)}{\alpha_{2}} N P L_{i t}+\underset{(+)}{\alpha_{3} \Delta_{t / t+1}} N P L_{i t}+\underset{(+)}{\alpha_{4}} L_{i t}+\underset{(-)}{\alpha_{5}} \dot{y}_{i t} \\
& +\underset{(+)}{\alpha_{6} E R_{i t}}+\underset{(+)}{\alpha_{7} E R} H_{-} H_{i t}+\underset{(+/-)}{\alpha_{8}} T C R L_{i t}+\underset{(+)}{\alpha} S I G N_{i t}+\varepsilon_{i t},
\end{aligned}
$$

where $L L P_{i t}$ is the ratio of loan loss provisions (specific provisions plus general provisions) to total assets at the end of the year $t$ for bank $i$. We introduce the lagged dependent variable as explanatory variable to take into account a dynamic adjustment of $L L P_{i t}$. If banks adjust their provisions slowly to recognize potential losses against loans following a default event, then provisions could be systematically related to each period. The model accounts for the possibility that the use of discretionary LLP for one purpose is conditional on the effects of the other two motivations; this is done by jointly estimating the relationships between loan loss provisions and income smoothing, capital management and signaling behaviors. 
Equation (1) is estimated to compute the non discretionary component $\left(N D I S C_{i t}\right)$ and the discretionary component $\left(D I S C_{i t}\right)$ of LLP. We assume that these two components are linear functions of the variables included in equation (1). Thus, the non discretionary component of LLP is estimated as the sum of the products of its explanatory variable times the corresponding estimated coefficient from equation (1). The same method is used to compute the discretionary component.

\subsection{Empirical results}

As we consider a dynamic adjustment of LLP, equation (1) is estimated with the generalized method of moments (GMM) using first differences (Arellano and Bond, 1991) and orthogonal deviations (Arellano and Bover, 1995). The results are reported in Table 1. This estimation is robust to heteroskedasticity and autocorrelation. We also ensure that the correlations between exogenous variables are weak.

The coefficients on $N P L_{i t}\left(\alpha_{2}\right)$ and on $\Delta_{t / t+1} N P L_{i t}\left(\alpha_{3}\right)$ are significantly positive at the $1 \%$ level. This result implies that the cyclical evolution of non performing loans influences provisioning via the backwardlooking rules. Bank profits are therefore also influenced by the cyclicality of identified credit losses via loan loss provisions. The other variable introduced to assess the effect of expected credit losses on LLP choices, the ratio of loans to total asset $L_{i t}$, is not significant at the $10 \%$ level. The significant and negative coefficient for GDP growth $\left(\alpha_{5}\right)$ indicates that the macroeconomic situation is relevant, which strengthens the cyclical behavior of LLP. Business cycle influences financial strength of firms and households and therefore is closely related to problem loans. This implies not only an increase in specific provisions according to backwardlooking rules but also an increase in the general provisions as the GDP growth modifies the credit exposure of banks. The lagged dependent variable is also significant at the $1 \%$ level, which suggests that banks adjust their provisions gradually to recognize potential losses against loans.

Concerning the discretionary behaviors, our results show that poorly capitalized banks use LLP to manage regulatory capital. Provisions of poorly capitalized banks vary directly with their surplus regulatory capital $\left(\alpha_{8}>0\right)$. When regulatory capital surpluses of poorly capitalized banks are increasing, these banks can increase loan loss provisions ${ }^{11}$. Thus, poorly capitalized banks are less inclined in making LLP. The estimated

\footnotetext{
${ }^{11}$ To check for robustness, equation (1) was also ran with the variable total capital ratio (TCR). This variable is not significant. It means that only poorly capitalized banks use LLP to manage regulatory capital. Our other conclusions remain valid. These
} 
coefficient of the variable earnings before taxes and loan loss provisions $\left(\alpha_{6}\right)$ is significant and negative. This is not consistent with the hypothesis of an income smoothing behavior. On the contrary, banks reduce loan loss provisions when earnings before taxes and loan loss provisions increase. This result emphasizes the cyclicality in loan loss provisions already underscored by the non discretionary component since high earnings are recorded during economic upswings. Beside, the variable $E R_{-} H_{i t}$, accounting for banks with a relatively good performance, exhibits a positive and significant coefficient $\left(\alpha_{7}\right)$. This result suggests a non linearity in the relation between LLP and earnings. Banks with relatively good performances are more able to offset the cyclicality of loan loss provisions. However, wald tests shows that the total impact $\left(\alpha_{6}+\alpha_{7}\right)$ of earnings on loan loss provisions remains negative and significantly different from zero at the $5 \%$ level for banks with a relatively good performance. With regard to the signaling behavior, banks may use discretionary LLP to signal financial strength. We find that the coefficient on $\operatorname{SIGN}_{i t}\left(\alpha_{9}\right)$ is positive and significant, which is consistent with the signaling hypothesis.

We use the estimates of equation (1) to compute the non discretionary (NDISC) and the discretionary (DISC) components of LLP. It is assumed that these two components are linear functions of the different variables included in equation (1). Thus, they are estimated as the sum of the products of its explanatory variables times the corresponding estimated coefficients from equation (1). To check for robustness, we compute different non discretionary and discretionary variables. The following three non discretionary variables are computed for each of two methods of estimation (Arellano and Bond (1991) and Arellano and Bover (1995))

$$
\begin{aligned}
& N D I S C 1_{i t}=\alpha_{1} L L P_{i t-1}+\alpha_{2} N P L_{i t}+\alpha_{3} \Delta_{t / t+1} N P L_{i t}+\alpha_{4} L_{i t}+\alpha_{5} \dot{y}_{i t} \\
& N D I S C 2_{i t}=\alpha_{1} L L P_{i t-1}+\alpha_{2} N P L_{i t}+\alpha_{3} \Delta_{t / t+1} N P L_{i t}+\alpha_{5} \dot{y}_{i t} \\
& N D I S C 3_{i t}=\alpha_{1} L L P_{i t-1}+\alpha_{2} N P L_{i t}+\alpha_{3} \Delta_{t / t+1} N P L_{i t}
\end{aligned}
$$

The variable $N D I S C 1_{i t}$ includes all the variables which may explain NDISC as well as the the annual growth rate of GDP $\left(\dot{y}_{i t}\right)$ which affects the ability of borrowers to repay banks' assets. The variable NDISC $2_{i t}$ only

results are not presented in the paper but are available from the authors upon request. 
includes the significant variables at the $10 \%$ level, which implies that the variable $L_{i t}$ is excluded compared to $N D I S C 1_{i t}$. The third non discretionary variable $\left(N D I S C 3_{i t}\right)$ excludes $\dot{y}_{i t}$ and the variable $L_{i t}$ which is not significant at the $10 \%$ level. On the same way, two discretionary components are computed

$$
\begin{aligned}
& D I S C 1_{i t}=\alpha_{6} E R_{i t}+\alpha_{7} E R_{-} H_{i t}+\alpha_{8} T C R L_{i t}+\alpha_{9} S I G N_{i t} \\
& D I S C 2_{i t}=\alpha_{7} E R_{-} H_{i t}+\alpha_{9} S I G N_{i t} .
\end{aligned}
$$

We consider the set of explanatory variables that are significant to compute the first discretionary variable, $D I S C 1_{i t}$. For the second one, we only keep the variables that may smooth loan loss provisions: $E R \_H_{i t}$ and $S I G N_{i t}$. Income smoothing and signaling behaviors may offset the evolution of non discretionary provisions, increasing loan loss reserves in good times. These provisions are accumulated when banks record strong earnings and signal their strong earnings power. This occurs when banks are in a good financial situation and could positively affect banks' incentives to supply credits.

These discretionary and non discretionary variables are used to test the impact of provisioning behaviors on bank loans fluctuations.

\section{Credit fluctuations and provisioning practices}

\subsection{Specification of credit fluctuations}

An empirical model on bank lending fluctuations is used to investigate macroeconomic implications of bank's procyclicality behavior. Most theoretical models on bank lending fluctuations are drawn on Bernanke and Blinder (1988) which originally introduced the credit market equilibrium in a textbook IS-LM model. However, empirical investigation with panel data calls several digressions. The empirical model has to fit microeconomic data and explain credit fluctuations at the bank level. We use a methodology similar to Kashyap and Stein (1995) who originally proposed a reduced form dynamic equation for bank loans. The model we 
estimate is written as

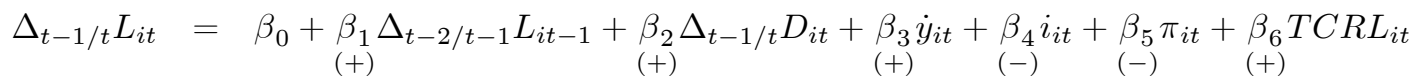

$$
\begin{aligned}
& +\beta_{7} N D I S C_{i t}+\beta_{8} N D I S C_{i t} * D u m+\beta_{9} D I S C_{i t}+u_{i t},
\end{aligned}
$$

where $\Delta_{t-1 / t} L_{i t}=\left(L_{i t}-L_{i t-1}\right) / 0.5\left(T A_{i t}+T A_{i t-1}\right) ; T A_{i t}$ is the total asset; $\Delta_{t-1 / t} D_{i t}$ is the growth rate of deposits between year $(t-1)$ and $t ; \dot{y}_{i t}$ is the GDP growth rate between the year $(t-1)$ and $t$; $i_{i t}$ is the money market rate; $\pi_{i t}$ is the inflation rate; $T C R L_{i t}$ equals (total capital ratio-8)/8 when observations for bank $i$ are in the first quartile of the total capital ratio (TCR) and 0 otherwise; $N D I S C_{i t}$ equals to $N D I S C 1_{i t}, N D I S C 2_{i t}$ or $N D I S C 3_{i t}$; DISC $C_{i t}$ equals to $D I S C 1_{i t}$ or $D I S C 2_{i t} ; N D I S C_{i t} * D u m$ equals to the non discretionary variable $\left(N D I S C 1_{i t}, N D I S C 2_{i t}\right.$ or $\left.N D I S C 3_{i t}\right)$ multiplied by a dummy variable which takes the value of 1 if the bank $i$ is classified as poorly capitalized and 0 otherwise.

Three groups of variables are considered in the model. Firstly, three macroeconomic variables are introduced. By including inflation and GDP growth rate, the model accounts for the economic environment. We should find a positive sign for the GDP growth rate $\left(\beta_{3}>0\right)$ since this variable is related to loan demand. The annual inflation rate should have a negative sign $\left(\beta_{5}<0\right)$. The sign of the coefficient associated with the money market rate should be negative $\left(\beta_{4}<0\right)$ according to the effect of a contractionary monetary policy on bank lending.

Secondly, we consider bank specific variables. We expect a positive relationship between bank loans fluctuations and the growth rate of deposits between year $(t-1)$ and $t\left(\beta_{2}>0\right)$. Furthermore, one variable is computed to take into account the bank capital channel, $T C R L_{i t}$. We should find a positive sign for the coefficient associated to $T C R L_{i t}\left(\beta_{6}>0\right)$ since the regulatory capital requirements should represent a constraint for poorly capitalized banks.

Finally, three variables are introduced to analyze the relationship between loan loss provisions and credit supply fluctuations. First, the non discretionary component of LLP $\left(N D I S C_{i t}\right)$ takes up reserves that banks have to charge to offset their problem loans. This component of loan loss provisions is therefore expected to reduce bank's incentive to expand its credit supply $\left(\beta_{7}<0\right)$ as it directly affects profits. During a downturn, 
the overall return on lending is particularly affected by the upsurge in loan loss provision resulting from backward looking rules. We expect a negative coefficient whatever the non discretionary variable considered: $N D I S C 1_{i t}, N D I S C 2_{i t}$ or $N D I S C 3_{i t}$. Second, we introduce an interaction variable $N D I S C_{i t} * D u m(D u m$ is a dummy variable which takes the value of 1 if the bank $i$ is classified as poorly capitalized) to test if there is non-linearity in the relation between non discretionary provisions and credit fluctuations. Indeed the effect of non discretionary provisions on credit fluctuations could be stronger for poorly capitalized banks $\left(\beta_{8}<0\right)$ since these banks cannot use a capital buffer to face an upsurge in loan losses. Third, we consider a discretionary variable: $D I S C 1_{i t}$ or $D I S C 2_{i t}$. The second one takes only into account discretionary behaviors that may have a counterbalancing effect on the cyclical evolution of non discretionary provisions: the income smoothing and the signaling. Such provisions are made when banks are in a good financial situation which could positively affect their ability to supply credits. We therefore expect a positive relationship between the discretionary variable $D I S C 2_{i t}$ and credit fluctuations in equation (7) $\left(\beta_{9}>0\right)$. The discretionary variable $D I S C 1_{i t}$ accounts for different behaviors. As the capital management behavior may have no clear effect on the cyclicality of bank lending and as the variable $E R_{i t}$ does not have the expected sign, the sign of the coefficient associated with the discretionary variable $D I S C 1_{i t}$ is unknown.

\subsection{Results}

The estimation of equation (7) is performed with the generalized method of moments (GMM). This method is relevant because the provisioning constraints (variables $N D I S C_{i t}$ and $D I S C_{i t}$ ) are built using the coefficients from the regression of equation (1) and therefore contains measurement error. In addition, the lag of the endogenous variable can lead to a simultaneity bias. These variables are therefore instrumented. Table 2 reports estimates obtained using the GMM estimator proposed by Arellano and Bover (1995) ${ }^{12}$. As we have three different non discretionary variables $\left(N D I S C 1_{i t}, N D I S C 2_{i t}\right.$ and $\left.N D I S C 3_{i t}\right)$ and two different discretionary variables $\left(D I S C 1_{i t}\right.$ and $\left.D I S C 2_{i t}\right)$, Table 2 displays results for six estimations ${ }^{13}$.

\footnotetext{
${ }^{12}$ Equation (7) is also estimated with the GMM estimator proposed by Arellano and Bond (1991). These results are similar to the ones obtained with the GMM estimator of Arellano and Bover (1995). They are not presented in the paper but are available from the author upon request.

${ }^{13}$ To check for robustness we also introduce in equation (7) the variation of total assets to take into account structural breaks which may affect the credit supply after a merger/acquisition. This variable, which is strongly correlated with the growth rate of deposits, is positive and significant for the six estimations. Overall, the vast majority of conclusions remain valid. These results are not presented in the paper but are available from the authors upon request.
} 
As expected, macroeconomic variables are relevant in credit fluctuations in all estimates. The coefficient of the GDP growth rate $\left(\beta_{3}\right)$ is significant and positive whereas the coefficient of the inflation rate $\left(\beta_{5}\right)$ is negative and significant. The coefficient of the money market interest rate $\left(\beta_{4}\right)$ is significant and negative. It means that monetary policy affects bank lending. We also find that banks use deposits to expand credit as the coefficient $\beta_{2}$ is positive and significant.

With regard to the institutional constraints, we find that the coefficient associated with the regulatory capital requirements for poorly capitalized banks $\left(\beta_{6}\right)$ is positive and significant at the $1 \%$ level, which is consistent with the bank capital channel. These banks are therefore constrained in their lending activities.

The provisioning rules also appear relevant in all estimates. Non discretionary loan loss provisions $\left(\beta_{7}\right)$ affect credit fluctuations negatively and significantly at the $1 \%$ level (this result is also supported with the Arellano and Bond (1991) estimator). Backward-looking provisioning rules therefore amplify credit cycle: weak specific provisions during upswing phases encourage banks to expand credit whereas the sudden identification of problem loans during downturns constrains banks to make provisions, which reduces their incentive to supply new credits. As expected, poorly capitalized banks appear more constrained by the provisioning system. Indeed, the coefficient associated by the interacting term $N D I S C_{i t} * D u m$ is negative and significant. Jordan et al. (2002) emphasize that the cyclicality of loan loss provisions is reflected in bank capital. Indeed, bank capital can also be used to face expected credit losses following a sudden quality deterioration of the loan portfolio. Capital requirements force poorly capitalized banks to shrink further lending when non discretionary provisions increase.

Estimation of the effect of discretionary provisions does not provide conclusive results. Coefficients associated with variable $D I S C 1_{i t}\left(\beta_{9}\right)$ are negative and significant at the $1 \%$ level $^{14}$. Strong discretionary provisions could therefore negatively affect bank lending like non discretionary provisions but $\beta_{9}$ is significantly weaker in absolute value than $\left(\beta_{7}\right)$. Discretionary provisions are therefore less relevant than non discretionary provision to explain bank lending behavior. In addition, $D I S C 1_{i t}$ merges several discretionary behaviors which makes difficult the interpretation of this result. Variable $D I S C 2_{i t}$ takes only into account provisions made for an income smoothing and/or a signaling purposes. This variable is significant at the $1 \%$

\footnotetext{
${ }^{14}$ However, the Arellano and Bond (1991) estimator gives similar result only with specification (7.1).
} 
level with the expected positive sign in specifications (7.4) and (7.6) but it is not significant at the $10 \%$ level in specification $(7.5)^{15}$. Thus we do not find a robust relation between the discretionary variable $D I S C 2_{i t}$ and credit fluctuations. Moreover, even if the coefficient associated with variable $D I S C 2_{i t}\left(\beta_{9}\right)$ is significant and positive, it is always significantly weaker in absolute value than $\beta_{7}$ and then its positive impact on bank lending is limited. As a result, these discretionary provisions are made when banks are in a good financial situation but this provisioning behavior does not seem necessarily relevant to explain bank lending behavior.

\section{Credit cycle and dynamic provisioning}

The model estimated in this paper concerns bank lending fluctuations. Long term and short term factors cannot be properly isolated since panel data with a short time period are used. However, the accounting constraint - linked to the evolution of non discretionary provisions - is relevant for short term fluctuations. This factor is driven by the cyclicality of identified credit losses as long as banks and regulators will not implement a proper recognition of expected credit losses. Several other banks' behaviors - for example, disaster myopia (Guttentag and Herring, 1986), herd behavior (Rajan, 1994) or the institutional memory hypothesis (Berger and Udell, 2003) - are more frequently highlighted to explain credit risk misevaluation and the credit cycle. The supervision of these behaviors is difficult because they are mainly related to the banks' perception of the business cycle. In addition, competition in the credit market could strengthen these behaviors. A conservative credit risk management strategy could implies earning returns under the competitive level which could involve a loss of market share during an economic expansion. Banks could therefore be incited to adopt a less conservative credit risk policy. Conversely, the implementation of a forward-looking provisioning system could more easily reduce the credit cycle. Bank regulators can adopt this system unilaterally.

A forward-looking provisioning system could break or more precisely offset the correlation between non discretionary provisions and credit fluctuations. This system consists of implementing statistical provisions linking loan loss provisions with long term expected credit losses and not with contemporaneous problem loans. Statistical provisions are computed as the difference between expected credit losses and specific

\footnotetext{
${ }^{15}$ In addition, the Arellano and Bond (1991) estimator gives similar result only with specification (7.6).
} 
provisions, i.e. they can either be positive or negative. Banks therefore have to estimate precisely their expected credit losses per period using their own internal models or a standard approach developed by the regulator (Fernandez de Lis et al, 2001). As a result, banks build up statistical provisions during upswing phases - when contemporaneous problem loans and consequently specific provisions are weak compared to total loans - and draw down these "reserves" during downturns. Over the full business cycle, loan loss provisions are therefore smoothed.

Previous researches (Fernandez de Lis et al, 2001; Borio et al., 2001; Mann and Michael, 2002; Jiménez and Saurina, 2005) emphasize the effect of dynamic provisioning to smooth bank income and to stabilize bank capital. The improvement in the evaluations of both credit risks and bank profits explain these positive outcomes. Furthermore, our findings show that provisioning also influences credit fluctuations. Our estimations can be used to graphically illustrate (Figure 1) the relevance of backward-looking provisioning practices to amplify credit fluctuations. We represent the situation of poorly capitalized banks because estimations showed (with the variable $N D I S C_{i t} * D u m$ ) that their lending behavior is more influenced by their provisioning behavior and also because we would like to represent the average effect of $T C R L_{i t}$ on credit fluctuations. Figure 1 displays annual averages of credit fluctuations $\left(\Delta_{t-1 / t} L_{i t}\right)$ for poorly capitalized banks. Credit fluctuations are consistently positive on average from 1996 to $2003^{16}$. They are particularly strong in 1999 and 2000, respectively at $10.33 \%$ and 10.93\%. Figure 1 also shows annual growth rate of credit fluctuations defined as $\left(\left(\Delta_{t-1 / t} L_{i t}-\Delta_{t-2 / t-1} L_{i t-1}\right) / \Delta_{t-2 / t-1} L_{i t-1}\right)$, i.e. the speed of credit fluctuations. The growth rate of credit fluctuations records numerous swings, which is consistent with the occurrence of a credit cycle. From 1997 to 2000, credit fluctuations are increasing which leads to positive growth rates of credit fluctuations in 1998, 1999 and 2000 (respectively $24 \%, 57 \%$ and 6\%) and represents the upswing phase of the cycle. This cycle peaks in 2000 and then slowdowns in 2001 and 2002. Growth rates of credit fluctuations are therefore negative in 2001 and 2002 (respectively $-36 \%$ and $-2 \%$ ). In 2003, the growth rate of credit fluctuations is positive again (21\%). The growth rate of credit fluctuations is broken down into several variables according to equation (7). We only represent on Figure 1 annual contributions of deposits fluctuations $\left(\Delta_{t-1 / t} D_{i t}\right)$, GDP growth rate $\left(\dot{y}_{i t}\right)$, total capital ratio $\left(T C R L_{i t}\right)$ and non discretionary

\footnotetext{
${ }^{16}$ Figure 1 does not consider years 1994 and 1995 because few poorly capitalized banks provide data for the period $1993-1995$.
} 
provisions $\left(N D I S C_{i t}\right)$ to the growth rate of credit fluctuations. Contributions of deposits fluctuations are the main factor explaining the growth rate of credit fluctuations. In particular, they have a strong and positive contribution in $1999(27 \%)^{17}$ during the upswing phase and a negative one in 2001 (-12\%) during the slowdown. Contributions of the GDP growth rate and non discretionary provisions are procyclical. These two variables have positive contributions during the upswing phase. In 1998, 1999 and 2000 contributions of the GDP growth rate are respectively $4 \%, 2 \%, 8 \%$ and contributions of non discretionary provisions are respectively $10 \%, 3 \%$ and $5 \%$. In 2001 , the average GDP growth rate falls from $3.57 \%$ to $1.77 \%$, which explains the strong contribution of the GDP growth rate $(-17 \%)$ to the slowdown of credit fluctuations. Non discretionary provisions have a weak negative contribution to the slowdown (-3\% in 2001) which means that few credit losses had been identified during the slowdown. In 2003, the positive growth rate of credit fluctuations (21\%) is particularly supported by the contribution of non discressionary provisions (9\%) whereas contributions of other factors are closed to zero. Figure 1 shows therefore that non discretionary provisions, as the GDP growth rate, contribute to amplify credit fluctuations. Figure 1 also points out that poorly capitalized banks are affected by the regulatory capital constraint. In 1999, total capital ratio has a negative contribution $(-12 \%)$ to the strongly positive growth rate of credit fluctuations (57\%). A strong credit expansion (ceterus paribus) leads to a fall in total capital ratio which reduces the ability of banks to expand credits. In 1999, the growth rate of credit fluctuations would have therefore been stronger without the regulatory capital constraint, which means that this constraint helped to smooth the upswing phase of the cycle. In 2001, a negative contribution of total capital ratio could have been expected because the slowdown could have lead to a fall in banks equities. However, Figure 1 shows that the contribution of total capital ratio is closed to zero $(0.4 \%)$ in 2001 . Finally, we point out that contributions of non discretionary provisions to the growth rate of credit fluctuations displayed on Figure 1 result directly from an unsatisfactory backwardlooking provisioning system. This factor is not the main source of credit fluctuations, but it could be easily removed from the credit cycle. Non discretionary provisions would be smoothed in a dynamic provisioning system (Fernandez de Lis et al , 2001). This system could therefore remove the banks' incentive to grant

\footnotetext{
${ }^{17}$ This figure and next figures have to be compared with the growth rates of credit fluctuations. For example, in 1999, the contribution of deposits fluctuation is $27 \%$ and the growth rate of credit fluctuations is $57 \%$. Deposits fluctuation explains therefore around the half of the growth rate of credit fluctuation as it is displayed on Figure 1.
} 
new loans when non dicretionnary provisions are decreasing, i.e. when the expected credit risk could be underestimated.

Our research gets to the heart of the differences in opinion between financial supervisors and accounting authorities. Over recent years, different approaches have been proposed to change both national and international accounting standards ${ }^{18}$ in order to include more forward-looking practices. The Full Fair Value Accounting (FFVA) suggests that all financial instruments - including loans - should be measured at market value. As a result, gains and losses should be recognized in the profit and loss account as soon as they are expected. A dynamic provisioning system represents the main alternative to take into account more cautiously expected losses. Given the cyclicality of bank lending, our results support a dynamic provisioning system as it provides a more satisfactory institutional arrangement. Indeed, FFVA is not appropriate to support financial stability. It can enhance the procyclical character of bank lending because immediate recognition of unrealized value might reinforce the effects of shocks (Enria, 2004). It also increases banks' earnings and regulatory capital volatilities (Barth et al., 1995) which can impact the volatility of banks' balance sheets. Moreover, FFVA could affect the liquidity transformation role of banks and could reduce their contribution to inter-temporal smoothing (Freixas and Tsomocos, 2004). Furthermore, FFVA does not adequately recognize the specific nature of bank lending. It views banks as portfolio managers rather than as institutions that solve informational problems ${ }^{19}$. As a result, the banking industry and banking supervisor are opposed to FFVA (Chisnall, 2000).

\section{Conclusion}

The purpose of this research was to determine if the current provisioning system in Europe amplifies credit fluctuations. Using a panel of 186 European banks for the period 1992-2004, we empirically investigated the effect of LLP on bank lending fluctuations. In the first step, we analyzed whether the choice of LLP reflects identified credit losses (non discretionary LLP) and/or management objectives (discretionary LLP). Then, in the second step, we examined the variables which have an effect on bank credit fluctuations.

\footnotetext{
${ }^{18}$ For a more detailed discussion of this issue, see Borio et al. (2001).

${ }^{19}$ This is because the market value of banks' loan is difficult to define due to the underlying special information which is only available for banks (Berger et al., 1991).
} 
Our results show that macroeconomic variables are relevant to explain credit fluctuations. We also find that poorly capitalized banks are constrained in their lending activities. With regards to the provisioning rules, the results show that the non discretionary component of LLP amplifies the credit cycle. During an upswing, banks tend to underestimate expected credit risk and then reduce non discretionary LLP. Banks' incentives to grant new loans are therefore reinforced since lending costs are understated. Conversely, sudden identification of problem loans during a downturn constrains banks to make non discretionary provisions, which reduces their incentive to supply new credits. In addition, this effect is stronger for poorly capitalized banks since these banks cannot use a capital buffer to face an upsurge in loan losses. On the contrary, the discretionary component of LLP does not seem relevant to explain credit fluctuations.

Our findings are consistent with the call for the implementation of a forward-looking principle in Europe through a dynamic provisioning system as in Spain and Portugal. Such dynamic provisioning system will require to modify accounting rules. The bank regulatory capital which incorporates general provisions up to a ceiling would also need to be changed in order to solely cover unexpected losses. The adoption of the dynamic provisioning system at the European level may imply to harmonize accounting and taxes rules which are very different across countries.

\section{References}

Ahmed, A. S., Takeda, C., Thomas, S., 1999. Bank loan loss provisions: a re-examination of capital management, earnings management and signaling effects. Journal of Accounting and Economics, 28, 1-26.

Altunbas, Y., Fazylov, O., Molyneux, P., 2002. Evidence on the bank lending channel in Europe. Journal of Banking and Finance, 26, 2093-2110.

Arellano, M., Bond, S.R., 1991. Some Tests of Specification for Panel Data: Monte Carlo Evidence and an Application to Employment Equations. Review of Economic Studies, 58, 277-297.

Arellano, M., Bover, O., 1995. Another Look at the Instrumental Variables Estimation of Errorcomponents Models. Journal of Econometrics, 68, 29-51.

Arpa, M.G., Ittner, A., Pauer, F., 2001. The influence of macroeconomic developments on Austrian banks: implications for banking supervision. BIS Papers. 1.

Asea, P.K., Blomberg, B., 1998. Lending cycles. Journal of Econometrics, 83, 89-128.

Beaver, W.H., Engel, E., 1996. Discretionary behavior with respect to allowances for loan losses and the behavior of security prices. Journal of Accounting and Economics, 22, 177-206.

Barth M.M., Landsman W.R., Wahlen, J.M., 1995. Fair value accounting: Effects on banks' earnings volatility, regulatory capital, and value of contractual cash flows. Journal of Banking and Finance, 19, 577605 .

Berger, A.N., Udell, G.F., 2003. The institutional memory hypothesis and the procyclicality of bank lending behavior. FEDS Working Paper No. 2003-02

Bernanke, B.S., Blinder, A.S., 1988. Credit, Money, and aggregate demand. NBER Working Paper ${ }^{\circ}$ 2534 . 
Bernanke, B.S., Gertler, M., 1995. Inside the black box: the credit channel of monetary policy transmission. Journal of Economic Perspectives, 9, 27-48.

Bernanke, B.S., Lown, C.S., 1991. The credit crunch. Brooking Papers on Economic Activity, 2, 205-248.

Bikker, J.A., 2004. Cyclical patterns in profits, provisioning and lending of banks. In Competition and efficiency in a unified European banking market, 241-273. Edward Elgar.

Bikker, J.A., Metzemakers, P., 2005. Bank provisioning behavior and procyclicality. Journal of International Financial Markets, Institutions and Money, 15(2), 141-157.

Borio, C., Furfine, C., Lowe, P., 2001. Procyclicality of the financial system and financial stability: issues and policy options. BIS Papers 1.

Brinkmann, E.J., Horvitz, P.M., 1995. Risk-based capital standards and the credit crunch. Journal of Money, Credit and Banking, 27(3), 848-863.

Cavallo, M., Majnoni, G., 2001. Do banks provision for bad loans in good time? Empirical evidence and policy implications. World Bank Working Paper \#2619.

Chami, R., Cosimano, T.F., 2001. Monetary policy with a touch of Basel. IMF Working Paper 01/151.

Chisnall, P., 2000. Fair value accounting - an industry view. Bank of England, Financial Stability Review, December.

Clerc, L., Drumetz F., Jaudoin O., 2001. To what extent are prudential and accounting arrangements pro- or countercyclical with respect to overall financial conditions? BIS Papers. 1.

Cortavarria, L., Dziobek, C., Kanaya, A. Song, I., 2000. Loan review, provisioning, and macroeconomic linkages. IMF, Working Paper, 00/195.

Crockett, A., 2000. Marrying the Micro and Macro-prudential dimensions of financial stability. BIS Review 76.

Ehrmann, M., Gambarcota, L., Martinez-Pagès, J., Sevestre, P., Worms, A., 2003. Financial system and the role of banks in monetary policy transmission in the Euro Area. In: Monetary policy transmission in the Euro area. Angeloni, I., Kashyap, A., Mojon. B. (Eds), Cambridge University Press.

Enria A., 2004. Fair value accounting and financial stability. ECB Occasional Paper Series, 13.

Fernandez de Lis, S., Martinez Pagès, J., Saurina, J., 2001. Credit growth, problem loans and credit risk provisioning in Spain. BIS Papers. 1.

Freixas, X., Tsomocos D.P., 2004. Book vs. Fair Value Accounting in Banking, and Intertemporal Smoothing. Oxford Financial Research Centre Working Paper Series, 2004-FE-13.

Furfine, C., 2001. Bank portfolio allocation: the impact of capital requirements, regulatory monitoring and economic conditions. Journal of Financial Services Research, 20, 33-56.

Gambacorta, L., Mistrulli, P.E., 2004. Does bank capital affect lending behavior? Journal of Financial Intermediation, 13, 436-457.

Gambacorta, L., 2005. Inside the bank lending channel. European Economic Review, 49, 1737-1759.

Guttentag, J.M., Herring, R.J., 1984. Credit rationing and financial disorder. Journal of Finance, 39, 1359-82.

Guttentag, J.M., Herring, R.J., 1986. Disaster myopia in international banking. Essays in International Finance, 164, International Finance Section, Princeton University.

Hancock, D., Wilcox, J.A., 1998. The credit crunch and the availability of credit to small businesses. Journal of Banking and Finance, 22, 983-1014.

Hausman, J.A., 1978. Specification Tests in Econometrics. Econometrica, 46, 1251-1271.

Jackson, P., Lodge, D., 2000. Fair Value Accounting, capital standards, expected loss provisioning and financial stability. Bank of England, Financial Stability Review, June.

Jiménez, G., Saurina, J., 2005. Credit cycles, credit risk, and prudential regulation. Bank of Spain, Working Paper, 0531.

Joint Working Group of Standard Setters. 2000. Financial instruments and similar items. Draft Standards and Basis for Conclusions.

Jordan, J., Peek, J., Rosengren, E., 2002. Credit risk modeling and the cyclicality of capital. Federal Reserve Bank of Boston, paper prepared for a conference on Changes in risk through time: measurement and policy options, BIS, Basel.

Kashyap, A.K., Stein, J.C., 1995. The impact of monetary policy on bank balance sheets. Carnerige Rochester Conference Series on Public Policy, 42, 151-195. 
Kashyap, A.K., Stein, J.C., 2000. What do a million observations on bank say about the transmission of monetary policy. The American Economic Review, 90, 407- 428.

Keeton, W.R. 1999. Does faster loan growth lead to higher loan losses? Federal Reserve Bank of Kansas City, Economic Review.

Kishan, R.P., Opiela, T.P., 2000. Bank size, bank capital, and the bank lending channel. Journal of Money, Credit and Banking, 32(1), 121-141.

Laeven, L., Majnoni, G., 2003. Loan Loss Provisioning and Economic Slowdowns: Too Much, Too Late? Journal of Financial Intermediation, 12(2), 178-197.

Liu, C.C., Ryan, S.G., Wahlen, J.M., 1997. Differential valuation implications of loan loss provisions across banks and fiscal quarters. The Accounting Review, 72(1), 133-146.

Lobo, G.J., Yang, D.H., 2001. Bank managers' heterogeneous decisions on discretionary loan loss provisions. Review of Quantitative Finance and Accounting, 16, 223-250.

Lown, C., Morgan, D.P., 2006. The credit cycle and the business cycle: new findings using the loan officer opinion survey. Journal of Money, Credit, and Banking, forthcoming.

Mann, F., Michael, I., 2002. Dynamic provisioning: issues and application. Bank of England, Financial Stability Review, December.

Pain, D., 2003. The Provisioning Experience of the Major UK Banks: A Small Panel Investigation. Bank of England, Working Paper.177.

Peek, J., Rosengren, E.S., 1995. Bank regulation and credit crunch. Journal of Banking and Finance, 19, 679-692.

Peek, J., Rosengren, E.S., Tootell, G.M., 2003. Identifying the macroeconomic effet of loan supply shocks. Journal of Money, Credit, and Banking, 35(6), 931-946.

Poveda, R., 2000. Reform of the system of insolvency provisions. Bank of Spain, January.

Rajan, R.G., 1994. Why bank credit policies fluctuate: a theory and some evidence. The Quaterly Journal of Economics, 109, 399-441.

Shrieves, R.E., Dahl, D., 2002. Discretionary accounting and the behavior of Japanese banks under financial distress. Journal of banking and finance, 27(7), 1219-1243.

Trichet, J.C., 2000. Presentation of the 1999 Annual Report of the Commission Bancaire. Paris, 3 July.

Van den Heuvel, S.J., 2002. The bank capital channel of monetary policy. Mimeo, University of Pennsylvania.

Wagster, J.D. 1999. The Basel Accord of 1988 and the international credit crunch of 1989-1992. Journal of Financial Services Research, 15, 123-143.

Whalen, J.M., 1994. The Nature of Information in Commercial Bank Loan Loss Disclosures. The Accounting Review. 69(3), 455-478.

Zicchino, L., 2005., A model of bank capital, lending and the macroeconomy: Basel I versus Basel II. Bank of England Working Paper No. 270. 
Table 1: Non discretionary and discretionary components of LLP(equation (1))

\begin{tabular}{|c|c|c|}
\hline & $\begin{array}{c}(1.1) \\
\text { (Arellano-Bond) }\end{array}$ & $\begin{array}{c}(1.2) \\
\text { (Arellano-Bover) }\end{array}$ \\
\hline $\begin{array}{c}L L P_{i t}(-1) \\
\quad(+)\end{array}$ & $\begin{array}{c}0.2624^{\mathrm{a}} \\
(7.35)\end{array}$ & $\begin{array}{c}0.2723^{\mathrm{a}} \\
(8.09)\end{array}$ \\
\hline $\begin{array}{c}N P L_{i t} \\
\quad(+)\end{array}$ & $\begin{array}{c}0.0261^{\mathrm{a}} \\
(2.65)\end{array}$ & $\begin{array}{c}0.0248^{\mathrm{a}} \\
(2.94)\end{array}$ \\
\hline $\begin{array}{c}\Delta_{t / t+1} N P L_{i t} \\
(+)\end{array}$ & $\begin{array}{c}0.0009^{b} \\
(2.12)\end{array}$ & $\begin{array}{c}0.0011^{\mathrm{a}} \\
(2.75)\end{array}$ \\
\hline $\begin{array}{l}L_{i t} \\
(+)\end{array}$ & $\begin{array}{c}0.0029 \\
(1.30)\end{array}$ & $\begin{array}{c}0.0026 \\
(1.31)\end{array}$ \\
\hline $\begin{array}{l}\dot{y}_{i t} \\
(-)\end{array}$ & $\begin{array}{c}-0.0113^{\mathrm{a}} \\
(-2.53)\end{array}$ & $\begin{array}{c}-0.0120^{\mathrm{a}} \\
(-2.88)\end{array}$ \\
\hline $\begin{array}{c}E R_{i t} \\
(+)\end{array}$ & $\begin{array}{c}-0.3522^{\mathrm{a}} \\
(-11.78)\end{array}$ & $\begin{array}{c}-0.3541^{\mathrm{a}} \\
(-12.73)\end{array}$ \\
\hline $\begin{array}{c}E R_{-} H_{i t} \\
(+)\end{array}$ & $\begin{array}{c}0.2271^{\mathrm{a}} \\
(7.42)\end{array}$ & $\begin{array}{c}0.2204^{\mathrm{a}} \\
(7.53)\end{array}$ \\
\hline $\begin{array}{c}T C R L_{i t} \\
(+)\end{array}$ & $\begin{array}{c}0.4148^{\mathrm{a}} \\
(2.81)\end{array}$ & $\begin{array}{c}0.4190^{\mathrm{a}} \\
(2.95)\end{array}$ \\
\hline $\begin{array}{c}S I G N_{i t} \\
\quad(+)\end{array}$ & $\begin{array}{c}0.0299^{\mathrm{c}} \\
(1.83)\end{array}$ & $\begin{array}{c}0.0335^{\mathrm{b}} \\
(2.25)\end{array}$ \\
\hline J-stat & 45.16 & 43.23 \\
\hline Obs. & 739 & 739 \\
\hline
\end{tabular}

Note: $\mathrm{a}, \mathrm{b}$ and $\mathrm{c}$ indicate significance respectively at the $1 \%, 5 \%$ and $10 \%$ levels. $t$-statistics are corrected for heteroskedasticity following White's methodology.

Variable definitions: $L L P_{i t}$ : ratio of loan loss provisions to total assets at the end of the year $t$; $N P L_{i t}$ : ratio of non performing loans to gross loans at the end of the year $t ; \Delta_{t / t+1} N P L_{i t}$ : NPL growth rate between year $t$ and $(t+1) ; L_{i t}$ : ratio of loans to total assets at the end of the year $t ; \dot{y}_{i t}$ : GDP growth rate between the year $(t-1)$ and $t ; E R_{i t}$ : ratio of earnings before taxes and loan loss provisions to total asset; $E R_{-} H_{i t}$ : take the value of $E R_{i t}$ for banks with positive earnings before taxes and loan loss provisions and 0 otherwise; $T C R L_{i t}$ : $\left(T C R_{i t}-8\right) / 8$ when observations for bank $i$ are in the first quartile of the total capital ratio $(T C R)$ and 0 otherwise; $S I G N_{i t}$ : take the value of the one-year-ahead change of $E R_{i t}$. 
Table 2: Bank loan fluctuations (Arellano Bover (1995) estimator)

\begin{tabular}{|c|c|c|c|c|c|c|}
\hline & $(7.1)$ & $(7.2)$ & $(7.3)$ & $(7.4)$ & $(7.5)$ & $(7.6)$ \\
\hline $\begin{array}{c}\Delta_{t-1 / t} L_{i t}(-1) \\
(+)\end{array}$ & $\begin{array}{c}0.0268^{\mathrm{a}} \\
(8.40)\end{array}$ & $\begin{array}{c}0.0159^{\mathrm{a}} \\
(9.72)\end{array}$ & $\begin{array}{c}0.0124^{\mathrm{a}} \\
(6.63)\end{array}$ & $\begin{array}{c}0.0440^{\mathrm{a}} \\
(21.36)\end{array}$ & $\begin{array}{c}0.0430^{\mathrm{a}} \\
(9.98)\end{array}$ & $\begin{array}{c}0.0241^{\mathrm{a}} \\
(10.37)\end{array}$ \\
\hline $\begin{array}{c}\Delta_{t-1 / t} D_{i t} \\
(+)\end{array}$ & $\begin{array}{c}0.2270^{\mathrm{a}} \\
(71.34)\end{array}$ & $\begin{array}{l}0.2363^{\mathrm{a}} \\
(132.62)\end{array}$ & $\begin{array}{l}0.2389^{\mathrm{a}} \\
(132.60)\end{array}$ & $\begin{array}{c}0.2517^{\mathrm{a}} \\
(55.87)\end{array}$ & $\begin{array}{l}0.2716^{\mathrm{a}} \\
(130.51)\end{array}$ & $\begin{array}{r}0.2611^{\mathrm{a}} \\
(117.02)\end{array}$ \\
\hline $\begin{array}{l}\dot{y}_{i t} \\
(+)\end{array}$ & $\begin{array}{c}0.9673^{\mathrm{a}} \\
(28.06)\end{array}$ & $\begin{array}{r}0.9644^{\mathrm{a}} \\
(59.42)\end{array}$ & $\begin{array}{l}1.099^{\mathrm{a}} \\
(49.85)\end{array}$ & $\begin{array}{c}0.8865^{\mathrm{a}} \\
(50.23)\end{array}$ & $\begin{array}{c}0.9329^{\mathrm{a}} \\
(28.61)\end{array}$ & $\begin{array}{r}1.0406^{\mathrm{a}} \\
(86.82)\end{array}$ \\
\hline $\begin{array}{l}i_{i t} \\
(-)\end{array}$ & $\begin{array}{c}-0.5383^{\mathrm{a}} \\
(-20.89)\end{array}$ & $\begin{array}{c}-0.5050^{\mathrm{a}} \\
(-31.32)\end{array}$ & $\begin{array}{r}-0.4860^{\mathrm{a}} \\
(-36.58)\end{array}$ & $\begin{array}{c}-0.4955^{\mathrm{a}} \\
(-27.64)\end{array}$ & $\begin{array}{c}-0.5414^{\mathrm{a}} \\
(-6.95)\end{array}$ & $\begin{array}{r}-0.4172^{\mathrm{a}} \\
(-34.35)\end{array}$ \\
\hline $\begin{array}{c}\pi_{i t} \\
(-)\end{array}$ & $\begin{array}{c}-0.3903^{\mathrm{a}} \\
(-11.44)\end{array}$ & $\begin{array}{c}-0.4525^{\mathrm{a}} \\
(-24.77)\end{array}$ & $\begin{array}{c}-0.3814^{\mathrm{a}} \\
(-15.64)\end{array}$ & $\begin{array}{c}-0.3830^{\mathrm{a}} \\
(-13.26)\end{array}$ & $\begin{array}{c}-0.6597^{\mathrm{a}} \\
(-15.37)\end{array}$ & $\begin{array}{r}-0.2993^{\mathrm{a}} \\
(-18.51)\end{array}$ \\
\hline $\begin{array}{c}T C R L_{i t} \\
\quad(+)\end{array}$ & $\begin{array}{r}0.1985^{\mathrm{a}} \\
(29.12)\end{array}$ & $\begin{array}{r}0.1874^{\mathrm{a}} \\
(55.97)\end{array}$ & $\begin{array}{r}0.2035^{\mathrm{a}} \\
(55.27)\end{array}$ & $\begin{array}{c}0.2040^{\mathrm{a}} \\
(16.17)\end{array}$ & $\begin{array}{c}0.2399^{\mathrm{a}} \\
(19.74)\end{array}$ & $\begin{array}{r}0.2264^{\mathrm{a}} \\
(40.15)\end{array}$ \\
\hline $\begin{array}{c}N D I S C 1_{i t} \\
(-)\end{array}$ & $\begin{array}{c}-0.0488^{\mathrm{a}} \\
(-8.14)\end{array}$ & - & - & $\begin{array}{c}-0.0526^{\mathrm{a}} \\
(-15.40)\end{array}$ & - & - \\
\hline $\begin{array}{c}N D I S C 2_{i t} \\
(-)\end{array}$ & - & $\begin{array}{c}-0.0683^{\mathrm{a}} \\
(-26.13)\end{array}$ & - & - & $\begin{array}{c}-0.0581^{\mathrm{a}} \\
(-10.02)\end{array}$ & - \\
\hline $\begin{array}{c}N D I S C 3_{i t} \\
(-)\end{array}$ & - & - & $\begin{array}{c}-0.0789^{\mathrm{a}} \\
(-25.19)\end{array}$ & - & - & $\begin{array}{r}-0.0872^{\mathrm{a}} \\
(-81.35)\end{array}$ \\
\hline$\underset{(-)}{N D I S C_{i t} * D u m}$ & $\begin{array}{c}-0.0250^{\mathrm{a}} \\
(-8.04)\end{array}$ & $\begin{array}{c}-0.0520^{\mathrm{a}} \\
(-27.36)\end{array}$ & $\begin{array}{r}-0.0450^{\mathrm{a}} \\
(-21.51)\end{array}$ & $\begin{array}{c}-0.0154^{\mathrm{a}} \\
(-2.58)\end{array}$ & $\begin{array}{c}-0.0619^{\mathrm{a}} \\
(-5.38)\end{array}$ & $\begin{array}{c}-0.0410^{\mathrm{a}} \\
(-8.26)\end{array}$ \\
\hline $\begin{array}{c}D I S C 1_{i t} \\
\quad(?)\end{array}$ & $\begin{array}{c}-0.0104^{\mathrm{a}} \\
(-4.71)\end{array}$ & $\begin{array}{c}-0.0056^{\mathrm{a}} \\
(-4.16)\end{array}$ & $\begin{array}{c}-0.0075^{\mathrm{a}} \\
(-6.56)\end{array}$ & - & - & - \\
\hline $\begin{array}{l}D I S C 2_{i t} \\
\quad(+)\end{array}$ & - & - & - & $\begin{array}{c}0.0189^{\mathrm{a}} \\
(6.47)\end{array}$ & $\begin{array}{c}0.0088 \\
(0.81)\end{array}$ & $\begin{array}{c}0.0236^{\mathrm{a}} \\
(10.62)\end{array}$ \\
\hline $\mathrm{J}-$ stat & 98.02 & 98.50 & 99.69 & 98.94 & 93.56 & 104.24 \\
\hline Obs. & 556 & 556 & 556 & 556 & 556 & 556 \\
\hline
\end{tabular}

Note: $\mathrm{a}, \mathrm{b}$ and $\mathrm{c}$ indicate significance respectively at the $1 \%, 5 \%$ and $10 \%$ levels. $t$-statistics are corrected for heteroskedasticity following White's methodology.

Variable definitions: $\Delta_{t-1 / t} L_{i t}$ : loans' variation of bank $i$ between years $(t-1)$ and $t / 0.5^{*}$ (total assets of year $(t-1)+$ total assets of year $t) ; \Delta_{t-1 / t} D_{i t}$ : growth rate of deposits between year $(t-1)$ and $t ; \dot{y}_{i t}$ : GDP growth rate between the year $(t-1)$ and $t ; i_{i t}$ : money market rate; $\pi_{i t}$ : inflation rate; $T C R L_{i t}:\left(T C R_{i t}-8\right) / 8$ when observations for bank $i$ are in the first quartile of the total capital ratio $(T C R)$ and 0 otherwise; NDISC1 $1_{i t}, N D I S C 2_{i t}$ and $N D I S C 3_{i t}$ : the three specifications of the non discretionary component of $L L P ; N D I S C_{i t}{ }^{*} D u m T C R L_{i t}$ : the non discretionary component of $L L P$ when observations for bank $i$ are in the first quartile of the total capital ratio $(T C R)$ and 0 otherwise; $D I S C 1_{i t}$ and $D I S C 2_{i t}$ : the two specifications of the discretionary component of $L L P$. 
Figure 1: Contributions to the growth rate of credit fluctuations

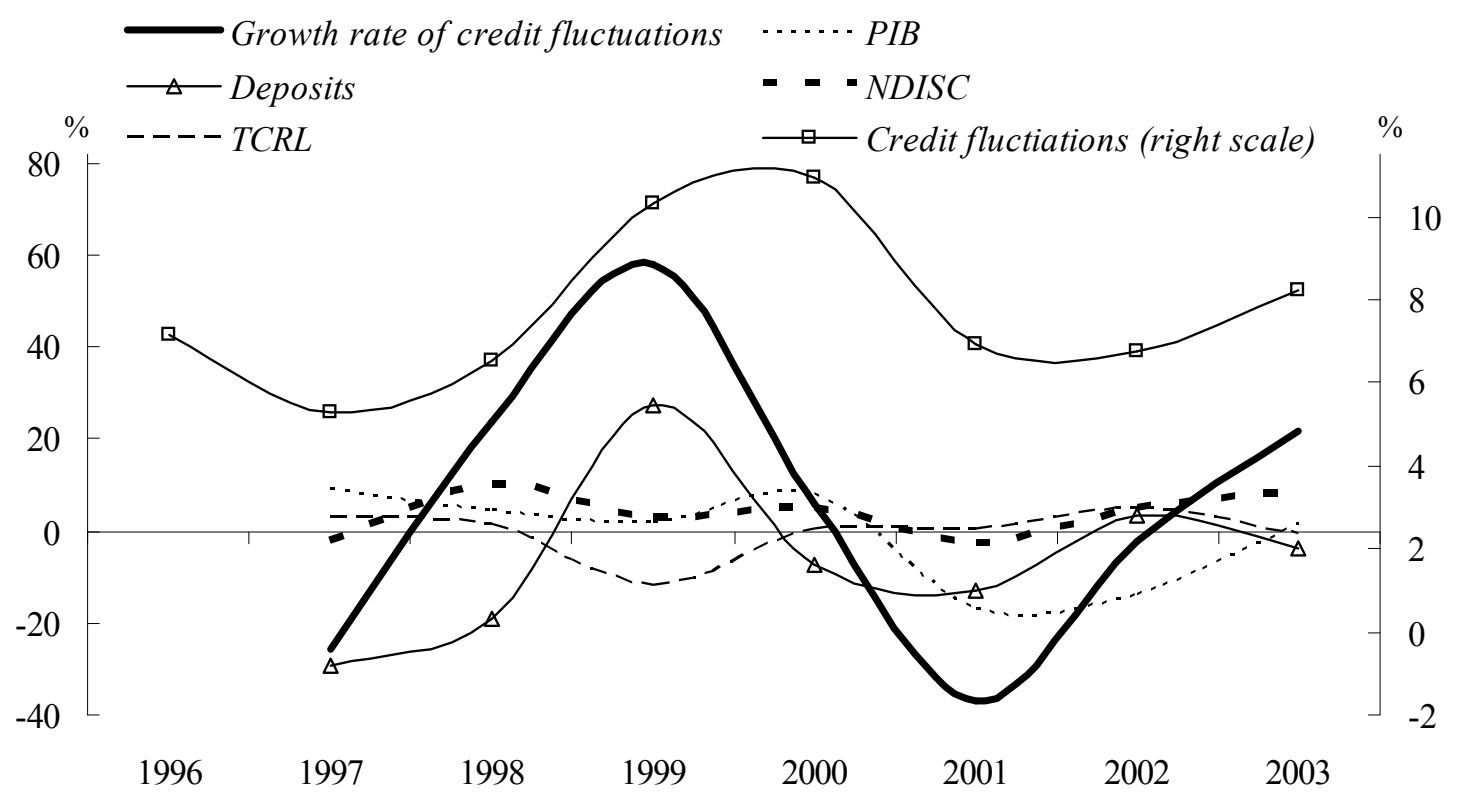

Note: This Figure uses average values for poorly capitalized banks of variables used in equation (7) and estimated coefficients of equation (7). Credit fluctuations correspond to annual averges for poorly capitalized banks of the endogenous variable $\left(\Delta_{t-1 / t} L_{i t}\right)$. The growth rate of credit fluctuations is defined as: $\left(\Delta_{t-1 / t} L_{i t}-\Delta_{t-2 / t-1} L_{i t-1}\right) / \Delta_{t-2 / t-1} L_{i t-1}$. Deposits, GDP, TCRL and NDISC respectively represent the contribution of deposits, GDP, total capital ratio and non discretionary provisions to the growth rate of credit fluctuations, computed as follow:

$$
\begin{gathered}
\frac{\Delta_{t-1 / t} L_{i t}-\Delta_{t-2 / t-1} L_{i t-1}}{\Delta_{t-2 / t-1} L_{i t-1}}=\frac{\Delta_{t-1 / t} D_{i t}-\Delta_{t-2 / t-1} D_{i t-1}}{\Delta_{t-2 / t-1} D_{i t-1}} \times \frac{\beta_{1} \Delta_{t-2 / t-1} D_{i t-1}}{\Delta_{t-2 / t-1} L_{i t-1}}+\frac{\dot{y}_{i t}-\dot{y}_{i t-1}}{\dot{y}_{i t-1}} \times \frac{\beta_{3} \dot{y}_{i t-1}}{\Delta_{t-2 / t-1} L_{i t-1}} \\
\quad+\frac{T C R L_{i t}-T C R L_{i t-1}}{T C R L_{i t-1}} \times \frac{\beta_{6} T C R L_{i t-1}}{\Delta_{t-2 / t-1} L_{i t-1}}+\frac{N D I S C_{i t}-N D I S C_{i t-1}}{N D I S C_{i t-1}} \times \frac{\left(\beta_{7}+\beta_{8}\right) N D I S C_{i t-1}}{\Delta_{t-2 / t-1} L_{i t-1}}+u_{i t}
\end{gathered}
$$

where $u_{i t}$ is the change in credit fluctuation explain by the other variables taken into account in equation (7). 


\section{Appendix}

Table A1: Country of origin of banks

\begin{tabular}{|c|c|c|c|c|}
\hline \multirow[t]{2}{*}{ Country } & \multirow[t]{2}{*}{$\begin{array}{l}\text { Number of banks* } \\
\text { available under } \\
\text { Bankscope Fitch } \\
\text { IBCA }\end{array}$} & \multirow[t]{2}{*}{$\begin{array}{l}\text { Number of } \\
\text { banks retained } \\
\text { in our sample }\end{array}$} & \multicolumn{2}{|c|}{$\begin{array}{l}\text { Total loans of banks } \\
\text { retained in our } \\
\text { sample / Total loans } \\
\text { of banks available } \\
\text { under Bankscope } \\
\text { Fitch IBCA }(\%)\end{array}$} \\
\hline & & & 1992 & 2004 \\
\hline Austria & 145 & 1 & 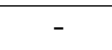 & 12.73 \\
\hline Belgium & 81 & 2 & - & 37.72 \\
\hline Denmark & 93 & 14 & - & 87.29 \\
\hline Finland & 13 & 1 & - & 32.06 \\
\hline France & 461 & 31 & 3.01 & 39.97 \\
\hline Germany & 456 & 4 & - & 46.98 \\
\hline Greece & 29 & 0 & - & - \\
\hline Ireland & 48 & 3 & 39.24 & 60.2 \\
\hline Italy & 272 & 83 & - & 72.18 \\
\hline Luxembourg & 147 & 0 & - & - \\
\hline Netherlands & 73 & 1 & - & - \\
\hline Norway & 21 & 6 & 12.09 & 30.45 \\
\hline Portugal & 40 & 11 & 28.24 & 91.99 \\
\hline Spain & 137 & 13 & 28.56 & 83.05 \\
\hline Sweden & 30 & 6 & 97.66 & 93.56 \\
\hline Switzerland & 270 & 1 & - & 39.56 \\
\hline UK & 197 & 9 & 53.7 & 27.55 \\
\hline Total & 2513 & 186 & - & - \\
\hline Mean & - & - & 37.50 & 53.95 \\
\hline
\end{tabular}

Table A2: Descriptive statistics for European commercial and cooperative banks, on average over the period 1992-2004.

\begin{tabular}{lcccccccc}
\hline \hline & $L$ & $\Delta L$ & $D$ & $E$ & $N P L$ & $L L P$ & $T C R$ & $R O A$ \\
\hline \hline Mean & 58.53 & 6.51 & 65.67 & 7.22 & 5.08 & 0.41 & 12.43 & 0.61 \\
Max & 97.89 & 48.02 & 92.32 & 75.84 & 29.02 & 3.76 & 39.32 & 3.09 \\
Min & 11.63 & -25.77 & 12.10 & 1.55 & 0.00 & -0.35 & 6.01 & -6.09 \\
Std & 16.25 & 7.75 & 14.56 & 4.43 & 4.37 & 0.36 & 4.26 & 0.54 \\
\hline
\end{tabular}

Variable definitions: All variables are in percentage. $L$ : loans/total assets; $\Delta L$ : loans' variation of bank $i$ between years $(t-1)$ and $t / 0.5^{*}$ (total assets of year $(t-1)+$ total assets of year $\left.t\right) ; D$ : deposits/total assets; $E$ : equity/total assets; NPL: non-performing loans/gross loans; LLP: loan loss provisions/total assets; TCR: total capital ratio; $R O A$ : return on asset. 